\title{
Production of Single Cell Protein Using Mixed Culture of Toddy with Banana Fruit Juice: A Cost Effective Method
}

\author{
Rajendran S. ${ }^{*}$, Kapilan R. ${ }^{2}$, Vasantharuba $S .{ }^{1}$ \\ ${ }^{1}$ Department of Agricultural chemistry, University of Jaffna, Sri Lanka \\ ${ }^{2}$ Department of Botany, University of Jaffna, Sri Lanka \\ *rsaru2009@gmail.com
}

\begin{abstract}
Since the increase in low quality protein food has been an issue in the developing countries, there is a need to explore good alternative protein sources. This study attempted to compare the single cell protein (SCP) production with baker's yeast and mixed culture of toddy from banana fruit juice in the Liquid State Fermentation (LSF) system. Fermentation media composed of glucose $10 \mathrm{~g} / \mathrm{l} . \mathrm{MgSO}_{4} 0.5, \mathrm{NaCl} 0.1, \mathrm{CaCl}_{2} 0.1$ and $\mathrm{KH}_{2} \mathrm{PO}_{4} 1 \mathrm{~g} / \mathrm{l}$ as control medium inoculated with toddy and $100 \mathrm{ml} / \mathrm{l}(10 \%)$ of banana fruit juice was replaced instead of glucose for banana medium. When the culture growing conditions (inoculum size- baker's yeast: $0.5 \mathrm{~g}$ and natural toddy: $5 \mathrm{ml}$ ) of the fermentation processes were optimised separately, higher SCP production was achieved when time and temperature maintained as 3 days and $30^{\circ} \mathrm{C}$ respectively with $40.29 \%$ baker's yeast and $40.95 \%$ palmyrah toddy mix for banana medium. When the carbon source was replaced with 5\% fruit juice, the SCP production significantly increased to $40.87 \%$ and $41.18 \%$ with baker's yeast and toddy mix respectively. This comparative fermentation study with baker's yeast and palmyrah toddy mix revealed that palmyrah toddy mix produces significantly higher protein content than that of baker's yeast. Findings suggest that cheap and naturally available palmyrah toddy mix yield higher SCP than the expensive and processed baker's yeast in the banana extract added fermentation medium.
\end{abstract}

Keywords: Baker's yeast, Banana fruit extract, Palmyrah toddy mix, Single cell protein 